\title{
Ibsen's Little Eyolf: The Great Efforts of a Handicap Child in Achieving His Self - Actualization Needs
}

\author{
Imam Basuki dan Fafan $\mathbf{S}$ \\ Faculty of Humanities, University of Jember \\ imabas88@gmail.com
}

Diterima 21 November 2017/Disetujui 21 November 2017

\begin{abstract}
Abstrak
Artikel ini membahas Little Eyolf, sebuah drama karya Henrik Ibsen yang mengisahkan tentang seorang anak cacat, bernama Eyolf, yang sulit untuk memenuhi kebutuhan hidupnya karena kurang perhatian dari kedua orang tua dan lingkungan sekitarnya. Untuk mengkaji kasus ini sebuah metode induktif diterapkan untuk menganalisis masalah aktualisasi diri sebagai kebutuhan hidupnya. Kajian ini memfokuskan pada aktualisasi diri Eyolf dan bertujuan untuk mengetahui bagaimana Eyolf mewujudkan aktualisasi diri dalam hidupnya. Dengan lingkungan yang kurang mendukung, Eyolf lari dari kenyataan yang dihadapinya dengan mencoba memenuhi kebutuhan pada aktualisasi diri di wilayah imajinasinya. Semangat Eyolf untuk menemukan penyelamatan diri sangat terkait erat dengan teori.Maslow tentang kebutuhan dasar manusia. Oleh karenanya, dalam kajian ini diterapkan penelitian berbasis kualitatif. Tragisnya. penyelamalan yang Eyolf dapatkan berujung pada kematian. Namun orang tuanya akhirnya sadar dan menyesal karena telah mengabaikan kebutuhan Eyolf secara fisiologis, kenyamanan. percava di ri. rasa memiliki dan cinta. Hasil dari penelitian ini membuktikan bahwa untuk memenuhi kebutuhan utama dalam hidupnya, Eyolf sangat membutuhkan perhatian dan kasih saying dari orang tuanya namun hal semacam ini tidak pernah dia dapatkan selama $m$ asa kecilnya.
\end{abstract}

Kata kunci: aktualisasi diri, kebutuhan dasar manusia, kebutuhan fisiolosis.

\section{Introduction}

Little Eyolf (1894) is a drama written by Henrik Ibsen that portrays Norway society. It is a tragedy play. Tragedy play is a play that the main character makes blunder or gets tragic events in his her life. Sometimes tragedy is not only death in ending, but also in sorrows, such Stanford (2006: 74) states that, "Tragedy which focuses on life's sorrows and serious problems'". It portrays the life ofa child who suffered in his life. It tells ahout the child craving affection from his parents.

Affection is a warm gentle feeling of caring for or loving (Hornby. 2000: 20). The children are made by their parents at home, the development, and their decline of their personalities most depend on affection, care, and love ot'the parents. Moreover, many children get bad affection by their parents or other caretakers. Most of their parents do not care of the affection to their children, and most of them do not know ihai the bad affection gives negative impacts to their children's personality.

Based on the fact above, it is interesting to analyze the personality of Eyolf as the main character, and to know liow he yets scl(-actualization in his life. This drama tells about an intelligent boy who lives miserably. The name of the child is Eyolf. He lives 
with his parents and family; Allmers, Rita, and Wa's family, He is an unlucky boy, because he must live with paralyzed in one of his legs and Asia's family never loves him. Therefore, his parents and family do not care of the affection to Eyolf. and they do not know that the bad affection gives negative impacts to Eyolf s personality.

Hence this thesis discusses the deepest personality of Eyolf as the child craving affection from his parents. The relationship between personality' and needs problem of human daily life are very interesting to discuss. The main character is also a description of daily life. Parents are created together as a unity; it is an impossible thing to separate each other. The main point the writer wants to analyze is about the motivation of needs as Eyolf s self-actualization in Henrik Ibsen's Little Eyolf.

Little Eyolf is interesting to discuss because there are so many problems in his life; such as, his efforts to solve his problem, getting his needs until the achievement to get his self-actualization. The main character. Eyolf, is showed as the child craving affection done by adults, parents or other caretakers. Most plays are not only entertained to watch or read, but it also gives moral values to the readers.

\section{Research Methodology}

Since this research is the qualitative research, the data obtained is the qualitative ones. The qualitative data is non numeric data. It is used in order to comprehend the meaning of verbal words in the story. The data are collected through numerous written texts sorted from the analyzed story, in this case the data will be in the written yet verbal form. The qualitative data are gathered taken from Little'Eyolf written by Henrik Ibsen and any supportive literary criticism books, especially the ones that are related to the theory of Hierarchy of needs by Abraham Maslow.

The research is in the form of qualitative description. As the literary works revolve in many elements, for example characters and setting, the center of the analysis focuses on the character. Hence, the description of the research will only involve the surrounding environment which is closely related to this particular character. In relation to descriptive analysis, the data sorted are analyzed using the Maslow's theory to perform a plausible descriptive analysis.

Since the problem of self actualization on the main character is discussed, hierarchy of needs by Maslow is truly relevant to put forward. The theory is able to explain the basic needs of human which are crucial in the development of characters's psyche. The theory of needs is used in order to deliver a better understanding of human's psychological issues.

Thus, the approach used is psychological approach. This approach is employed-to study the phenomena and problems related to the characters's mind in relation to his acts and its development in the story. This issue happens in Eyolf as the main character 
since he could not fulfill his basic needs during his childhood. The blame is on his parents who have not given more affection and love to Eyolf.

This research is indeed inductive one. It is started with the analysis of the play in relation with the issue occurs to Eyolf as the main character who experiences lack of affection during his hardest moment as handicapped boy. Next, Maslow's theory of hierarchy of needs will give a result in how far the needs have been violated. In short, the analysis of the issues in the play will show how possible a human could react to the lack of needs such as physiological, safety, self esteem, belongingness and love needs. As the result, the theory will clearly explain how could possibly with low self actualization could end up to tragedy. Fortunately, this research also displays how to prevent the issue in such way by giving a more scientific study over the character.

\section{Result}

From, the data of Eyolf's self-actualization in Hendrik Ibsen's Little Eyolf, it is found that Little Eyolf portrays the efforts of Eyolf, the main male character, to achieve his self-actualization. "The Maslow's hierarchy of needs is established physiological needs, safety needs, belongingness and love needs, self-esteem needs and the last one is self-actualization.

Fist it shows that physiological needs are need well experienced by Eyolf since his father Mr. Allmers loves travelling over town and his mother Mrs. Rita does not care . to Eyolf at home, moreover he does not feel welcome at home. Second, His safety . needs. Eyolf's childhood experiences no safety because he has to see everyday quarrel over his parents. Hi escapes outside with his book to calm himself. The third need of Eyolf is belongingness and love needs which have never been on the first priority. This happens because Eyolf's mother sees him as a curse for the family. I he fourth need of Eyolf is esteem needs which is also impossible for Eyolf to posses. His parents however never trusts him of doing great things in the future. The last need of Eyolf is self actualization. This need is indeed impossible to get like any other needs since his parents never give a chance to Eyolf to act like he wants to

This research concludes that there are many motives for individual to achieve $\mathrm{h}$ is self-actualization but non physiological, safety, self esteem, belongingness and love needs are given to him, so Eyolf ends up with committing suicide.

\section{Discussion}

Imagination plays a big role in Eyolf mind because in real world he can not get self actualization. His environment never supports him to do so. Her mother is never patient to deal with Eyolf fantasy, it is not only because she has not patient but she even does not love Eyolf at all. Her mother sees Eyolf as a hinder between her and her husband. More to the self actualization. Eyolf has gone too far with his own fantasy making himself delusional. He cannot differentiate the difference between reality and 
fantasy. In the end of the slory. he has to live with his outmost challenge of life. He has loosened everything, his loneliness and disability lead him to the indiscretion. He was following his illusionary image of life by getting in to sea. Noticing he could not swim, Eyolf is dragged into the depth of the ocean and drowned with his memory of wonderful life.

Coming across an impressionable child, she tells him a preposterous tale, adpted from the old "Pied Piper" legends, of her method of fascinating her victims. The child, whose imagination has long dwelt on this personage, i8s i8n fact hypnotized by her her down to the sea, and watching her row away, torns dizzy, falls in, and is drowned.... I think in that in the poet's mind the Rat-Wife is the symbol of death, of the still, soft darkness" that is at one so fearful and so fascinating to humanity (Ibsen, 1894).

Tragedy is indeed in the end of the story. Eyolf has found its own redemption by going to the sea. This is another interesting assumption, that Eyolf must have experienced a mental disorder, or it is just another symbolism of helplessness of having no genuine love from her parents or people around him. Living in fantasy and imagination brings him peace, only in that place lie could gain acceptance. However this kind of acceptance does not come cheap. His death might also his dying effort to show his existence to the people around him and yes he succeeds. This subchapter discussion is integrated to the other subs since one data to another are highly related. To know the link of them is to comprehend the relation of each data. Hence the following subchapter will discuss further on how relation of self actualization could possibly be functional if the physiological needs and affection meet the subject.

\subsection{The Physiological Needs of Eyolf}

Maslow puts forward a theory that there are five levels of human needs which the individuals need have to be fulfilled in his life. Those are physiological needs, safety needs, belongingness and love need, self-esteem needs, and the need for self actualization. All of the needs are structured into a hierarchy of human needs. Physiological needs are awfully crucial to understanding of human behaviour. It is the biggest effect compared with all needs. It means that the major motivation must be physiological needs rather than any others. It must be contented before the individual motivates to the higher order of needs. For instance, somebody who is deficient in food, safety, love, and esteems would be most starving for food more strongly than for other needs.

Somebody cannot do anything else when physiological needs cannot be fulfilled. They are unable to attempt satisfaction of higher needs level. Maslow says:

For our chronically and extremely hungry man, Utopia can be defined simply as a place where there is a plenty of food. He tends to think that, if only he is guaranteed food for the rest of his life, .he will be perfectly happy and will never want anything more...... Freedom, love, community feeling, respect, philosophy...... Such a man may fairly be said to live by bread alone. 
(1976:258).

Parents have very important role to teach their children about the love, they must be taught about it as well as how to apply this love in their life. The children will follow what they see and hear from their parents, every act which they do will be known and followed by their children. In the home, the parents to speak, lo eat. to sleep and to behave as they are laugh by their parents because the first education for children begins from their house and it will influence their future life. In drama Little Eyolf . the main character, Eyolf, gets his biological needs and they consist of needs for oxygen, food, water, and a relatively constant body temperature from parents and family in his home. The following quotation proves it.

ASTA: (As she enters) Good morning, my dear Rita.

RITA: (Turns her head, and nods to her) What! Is that you, Asta? Come all the way from town so early?

ASTA: (Takes of her things, and lays them on a chair beside the door). Yes, such a restless feeling came over me. I felt I must come out to-day, and see how Eyolf was getting on- and you too. (Lays the portofolio on the table beside the sofa) So I took the steamer, and here I am.

\section{(Ibsen, 1894:9)}

From the quotation above, it gives an illustration of the atmosphere inside the house. Eyolf lives with his parents, Mr. Allmers and Mrs. Rita, and his aunt, Asta.

However, the only physiological need that is given by the parents is limited. This shows how lame the parents kids relationship in the story. Hence. Eyolf is the symbolism of the unwanted child. His paralyzed legs make his life even worse. To best of his life is sitting in the beach, and think of fantasy to escape from the torturing reality. Eyolf however should find his own ecstasy.

Mrs. Rita loves very much her husband, Mr. Allmers, but her deep love to Allmers has blinded her for her son's existence. It is proven that she admits that she could not be the mother of Eyolf. She regrets the act that she is the one who was delivering Eyolf to the world. The following quotation proves it.

ALLMERS: (Flashing out) Rita! Yo u do not know what you are saying !

RITA: (Trembling with emotion) It was in pain unspeakable that I brought

him into the world. But I bore it all with joy and rapture for your sake.

ALLMERS: (Warmly) Oh yes. I know, I know

\section{( Ibsen, 1894: 31 )}

It is not clear enough to explain about the physiological needs of Eyolf. He tries to fulfill the physiological needs on his owns. The message is learned for the parents, it is essential for the parents to provide a good affection for his children, parents is the mirror for his children. Every act which they did will be known and followed by his children. They speak, eal, sleep at home, but Eyolf do not give the physiological needs from his parents. 


\subsection{The Safety Needs of Eyolf}

The next level is safety needs. When physiological needs have been gratified, somebody may move to the higher order need that is often called the safety needs. Safety needs are the needs when the individual yearning for physical, safety and shelter, freedom from threat or security, calmness, certainty, order. Safety and Security needs include: Personal security, financial security, health and well being, safety needs against accidents or illness and their adverse impacts. Childhood experiences are memorable. Whatever has happened in the last time when he was a child, it will be always kept in his mind until he grows up. It is really essential for all parents to give a good education to their children, especially in their childhood. It will much influence to their growth of manner. Hence, it is the basic knowledge for them to become a good boy.

In the drama Little Eyolf, the main character. Eyolf has fulfilled his physiological needs and he will fulfill his next needs, safety needs. Eyolf has not fulfilled his safety needs because he is an unlucky boy. His father Mr. Allmers and his mother Mrs. Rita never think what Eyolf wants, they never give him care and affection. The following quotation proves it.

RITA: (Somewhat impatiently) Oh no; come now, I really cannot meddle with that... And what would you have Eyolf do ? He can't run about and play, you see-like other children

(Ibsen:1894:11)

RITA: And that was why you wanted to make a prodigy of poor little Eyolf.

ALLMERS: That was not what Iwanted. I wanted to make a happy human beingof him - that, and nothing more

(Ibsen, 1894:52)

Eyolf's childhood experiences shape his character when he is an adult, all of bad treatments from his surrounding makes him become cruel, vengeful and hottempered. When he has a power, he realizes to do his vengeance. He does not gel [he safety need when he was a child.

\subsection{The Belongingness and Love Needs of Eyolf}

After physiological and safety needs are fulfilled, the third layers of human needs are social and involve feelings of belongingness. This aspect of Maslow's hierarchy involves emotionally based relationships in general, such as Friendship. Intimacy, and Family. Hjelle and Zielger say that an individual motivated on this level longs for affectionate relationship with others, namely for a place in his or her family on reference groups (1976:259). Accordingly, the person will feel keenly the pangs of loneliness, social ostracism, friendlessness, and rejection, especially when induced by 
me absence of friends, relatives, a spouse or children. From the explanation we can conclude that this need involves emotionally relationship.

Eyolf gets his belongingness and love needs by building relationship with his parents, Mr.Allmers and Mrs.Rita as well as his aunt Asta's family. The quotation below proves it.

ASTA: But you haven't even touched the book! And yet you can look so happy and contented! That is not what you generally do-I mean when your work is going badly.

EYOLF: Who can that be? Oh tell me!

ALLMERS: Only wait_you may be sure he will come, and let us hear of him.

EYOLF: And what will you do then ?

ALLMERS: (Seriously) Then I will d go to the mountains again-

(Ibsen, 1894:13)

The quotation above proves that Eyolf does not get attention from his father and mother. The problem is even more complicated when Rita goes mad. She does not want Eyolf in her life.

Hurlock ( 1942: 185) says that

The child who is deprived out of opportunities to experience affection is seriously damaged. He is denied the ego-satisfying experience that being loved by others provides. And he is denied the intimate social relation which affection and love encourage.

The statement above explains that the affection of parents to their children is important because it gives good influence on the relationship within children and parents. The children, who deprive of affection, will deny almost the opportunities for joy and happiness, and it is not good for their children's personality.

\subsection{The Esteem Needs of Eyolf}

The fourth level of needs is the Esteem Needs. When someone needs for being loved and for loving others have been completed, they can move to the higher order needs. Maslow classifies these needs into two subsidiary sets. These are, first, the desire for competence, confidence, personal strength, adequacy, achievement, independence and freedom. Secondly, is the need for the respect of others, includes prestige, recognition, attention, status, reputation, appreciation ( 1976: 260- 261 ).

Hjelle and Zielger also say as follows:

Satisfaction of the self-esteem needs generates feelings and attitude of selfconfidence, worth, strength, capability, and of being useful and necessary in the world; in contrast the thwarting of these needs lerads to the feeling and attitudes of inferiority ineptness, weakness and helplessness.

( 1976: 261 ). 
From the explanation above, it means that all human have a need to be respected, to have sef-esteem. Esteem needs present the normal human desire to be accepted and valued by others.

In his esteem needs, Eyolf tries to fulfill the desire to respect and to be respected. He needs his parents' attention because they do not care of the affection to Eyolf. He never thiks that his problem is so hard. So Eyolf may develop balance and pleasant personalities to make his parents proud and satisfied. The proof is the following quotation.

EYOLF: An d I forgot to tell you, Papa-Borgheim has bought me a new bow. And he has taught me how to shoot with it too.

ALLMERS: And there now-that's just the sort of thing for you, Eyolf.

EYOLF: And next time he comes, I shall ask him to teach me to swim, too.

ALLMERS: To swim! Oh, what makes you want to learn swimming?

ALLMERS: ( With emotion, taking him in his arms ) You shall learn whatever you like-everything you really want.

(Ibsen, 1894: 14 )

Based on the quotation above, it is proved that Eyolf really an intelligent boy who lives miserably. He ask his father to teach him swimming but his father Mr. Allmers denied his desire. He tries to make his dream come true by practicing swimming although he must live with paralyzed legs.

The information above tells that Eyolf tries to fulfill the desire to respect and to be respected but his parents ignore all of his dream and his desire. Therefore, he escapes from reality and lives in his own world of fantasy. In the world of fantasy, he could do as he wants and get what he needs.

\subsection{The Self Actualization Needs of Eyolf}

The last and the highest level in the Maslow's hierarchy of human needs is the need for self actualization. Maslow expresses that characterized self actualization as the desire to become everything that one is capable of becoming ( Hjelle and Zielger, 1976:261 ). Self actualization is to become the total kind of person that one wants to become to reach the peaks of his or her potential, such as a musician must make music., an artist must paint., a poet must write. Furthermore, Maslow mentions that what a man can be, he must be. He must be true to his own nature (1970:46 ). From the illustration above, the needs for self actualization are the needs for growth, development and strive to use his potential to accomplish his self-fulfillment.

Unlike other boys, Eyolf has problem to perform his self actualization even when he wears a new clothes. His existence is never accepted by his surroundings because he has no complete legs; therefore, his dream of becoming a soldier also becomes a subject of mockery done by the other boys surrounding him. Eyolf is better off with the books. Moreover, his parents never give him motivation to get his self actualization. The 3 following quotation proves it.

EYOLF: Should I not take some books with me ? 
ALLMERS: No, no books after this. You had better go down to the beach to other boys.

EYOLF: (Shyly) No, Papa, I won't go down to the boys today. ALLMERRS: Why not ?

EYOLF: Oh, because I have these clothes on.

ALLMERS: (Knitting his brows) Do you mean that they make fun of - of your pretty clothes?

EYOLF: You see, they are so naughty, these boys. And then they say I can never be a soldier.

( Ibsen, 1894: 15 )

The above quotation proves that Eyolf has no place of self actualization. Inside the house he only sees madness and outside he can not go with other boys. His aunty asta rarely talks to him and the uncle never genuinely cares about him because his purpose is to get close to Rita. Here, through the process. Eyolf does not successfully achieve his self-actualization. He will onlv be succeed when all the laters of Maslow's hierarchy of human (physiological needs, safety needs, belongingness, and love needs, and esteem needs) are well gratified, so she/ he can achieve this highest level. From this last level someone can prove her.' his capacity in the way of reaching his willingness but Eyolf is a different story.

Last, his desperate need of acceptance leads him into an epic end. Ignorance makes his family blind. One time. Eyolf is missing and no one knows about his whereabouts. The next thing they know that there is a child that is drowned, they never really know and care about Eyolf. The last thing they will know is remorse. In the final story there is more clearly explanation about Eyolf's death as symbolization of his dying effort to get attention from his family, from people whom he knows. Eyolf's death makes his parents Mr. Allmers and Mrs. Rita unhappy. Eyolf is sinking down in the sea and he has passed so far the sea. In this case, Eyolf is suffering over there. Besides Allmers and Mrs. Rita want to help his child, Eyolf, they also want to see his child, Eyolf, before his death and say sorry for not caring of him in his whole life.

Mr. Allmers and Mrs. Rita have neglected their child. They do not think it's vain to care about their child. They have played with life and death and now the great open eyes of the stranger boy will be for ever upon them. Mr. Allmers's egoism prevented him from really loving child but himself. He was badly affected by desertions. No child deserves to suffer for the parents's mistakes..

\section{Conclusion}

The analysis on the needs of Eyolf's self-actualization in Hendrik Ibsen's Little Eyolf. readers find that Little Eyolf portrays the efforts of Eyolf, the main male character, to achieve his self-actualization. The theory used to analyze the data in the discussion is hierarchy of human needs by Abraham H Maslow. It has been mentioned in theoretical 
framework that there are many levels to get self- actualization. Those are physiological needs, safety needs, belongingness and love needs, self-esteem needs and the last one is self-actualization needs.

The first need of Evolf is physiological needs. He suffers in his childhood because his father, Mr. Allmers, loves travelling over towns and his mother, Mrs. Rita, does not care about Eyolf at home. Eyolf is unhappy at home because his parents ignore him. The second need of Eyolf is safety needs. Eyolf's childhood experiences unusual childhood including his handicapped leg. Hence, it is really essential for his parents, Mr. Allmers and Mrs Rita,to give a good affection to Eyolf, especially in his childhood but it never happens.

The third need of Eyolf is belongingness and love needs. He does not get belongingness and love needs from his parents.. His father Mr. Allmers never gives affection because he is busy writing Human Responsibility book at his room; moreover, he likes travelling over town. The fourth need of Eyolf is esteem needs. He tries to fulfill his desire to respect and to be respected from his father Mr. Allmers, and his mother Mrs. Rita but they always put no respect and affection to Eyolf in his life.

The last need of Eyolf is self actualization needs.. His father Mr. Allmers has been a restless and half reluctant slave to Mrs. Rita who has imperious temperament. Mr. Allmers has dreamed and theorized about responsibility and has kept Eyolf poring over his books. Mr. Allmers goes up into the infinite solitudes, yearning towards selfless love and filled with a profound and remorseful pity for the lot of poor maimed humanity. He will help Eyolf to bring $\mathrm{h}$ is desires into harmony with what lies attainable before him. He will create a conscious happiness in his mind.

This study concludes that there are many motives for individual to achieve his self-actualization. Firstly, he has to be able to fulfill his needs and to-solve the problems by believing and struggling for his self actualization. Secondly, it is crucial to convince ourselves that we can do what we want to be. as long as suitable with our talent and tries to actualize to make it true. The true happiness never comes if people do not work together to make it happens. Such an event has happened to Eyolf and his parents.

\section{References}

Blaster et. Al. 1997. How to Research. Philadelpia: Open University.

Boulton, Marjorie. 1968. The Anatomy of Drama. London: Routledge \&. Kegan Paul, Ltd.

Fatmawati, Ririn. 2011. Heathcliffs Self-actualbalion in Bronte's Wuthering Heights. Jember: Faculty of Letters Jember University. 
Ibsen's Little Eyolf: The Great Efforts of a Handicap Child in Achieving His Self-Actualization Needs (Imam Basuki dan Fafan S)

Hjelle, Larry A and Daniel J. Ziegler. 1976. Personality Theories: Basic Assumption, Research, and Application. USA: Me Graw. Hill, Inc.

Hornby, A.S. 2000. Oxford Advanced Learnei s Dictionary $7^{\text {th }}$ edition. Oxford: Oxford University Press.

Hurlock, Elizabeth B. 1972. Child Development International Student Edition.

Ibsen. Henrik. 1958. The Master Builder and Other Plays. New York: Penguin Books Ltd.

Kusumastuti, Virgi, Jatiningtyas. 2012. An Analysis on The Needs of Erin Grmvell 's Self-Actualization in Richard Lagravenese' s Freedom Writers, Jember: Faculty of Letters Jember University.

Maslow. Abraham. 1970. Motivation and Personality. New York: Harper \& Row.

McMillan. James H. 1992. Educational Research. Harper Collins.

Murray, Henry. 1951. Some Basic Psychological assumptions and conceptions. Dialectica.

Scott, Wilbur S. 1962. Five Approaches of Literary Criticism. New York: The Macmillan Company.

Shaw. Harry. 1972. Dictionary of Literary Terms. New York: Me. Grawhill, Inc.

Wellek, Rene and Austin Warren. 1956. Theory of Literature. New York: Harcourt. Brace and World, Inc. 